\title{
Markl opens Max-Planck's doors
}

\author{
The new enthusiasm for biotechnology in Germany is reflected by \\ Max-Planck's president.
}

\section{John Hodgson}

Hubert Markl has been president of the Max-Planck-Gesellschaft (MPG; Berlin), the organization that funds the elite of Germany's premier research community for just over a year. He characterizes himself as "a traditional evolutionary biologist," but some see him as more revolutionary than that. $\mathrm{He}$ wants to involve MPG's biology facilities more fully in the new wave of enthusiasm in German for biotechnology. And that has not made him universally popular.

Some suspect that Markl wants to mobilize the MPG's biological science resource in a wholesale fashion. "Some of my MaxPlanck colleagues think that [I] want to push them into applied research, into the hands of industry. . . Actually, I don't. I just want to have an open door policy, free exchange, open exchange." But on the question of intellectual freedom Markl insists that MPG must stand its ground. "There is no question that I will fight for our independence as any president has ever done."

Markl, relaxed but precise in both his appearance and speech, has as great a respect for MPG's traditions of independence as he does for his own scientific hero, Charles Darwin. Darwin, Markl points out, had no formal qualification in science and never taught at a university. He had the freedom to pursue his science largely because his own family and that of his wife, a member of Wedgwood family, was wealthy. This, he believes, has been, and should continue to be, the basis of the MPG's approach to funding. "The people who founded ... the MPG wanted to give the best researchers a lot of freedom and sufficient funds. Of course, nowadays MPG is married to the taxpayer: The government is our midwife, as it were."

The resources are certainly large. With $95 \%$ of its funding coming from either federal or Lander (state) government source's, the MPG currently spends around DM1.95 (US $\$ 2.18$ ) billion. It employs $\sim 11,000$ people of whom 2,700 are researchers. Around 40\% of MPG's activities are in biology.

MPG's emphasis on freedom is reflected in the organization of each of the 75 Max-Planck Institutes (MPIs) around individuals, their directors. The directors are people like Christiane Nüsslein-Volhard and Robert Huber, both recent Nobel Prize winners. Or like Jeff
Schell, a pioneer of plant molecular genetics and breeding who runs a department at an MPI in Cologne. As institute directors, all can undertake their work within a solid infrastructure supported by personnel, running expenses, and-most importantlyintellectual space.

But can this jealously guarded independence continue in a Germany whose government is now trying to galvanize a national biotech-

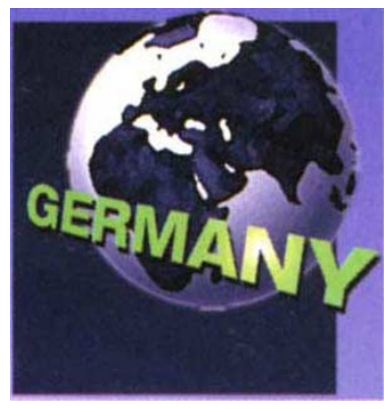

legal niceties proceed as planned] is access to people who are at the forefront of their respective fields.

One of the activities that has undeniably had an influence on German sentiments toward biotechnology has been the national biotechnology competition, BioRegio. But, if the hype is to be believed, the impact of the scheme has had an effect on the key industrial, academic and financial actors in Gernology effort? Hubert Markl believes that it can, and should. But he also feels that the time is right for the MPIs to open out to industry. "We don't have to be afraid. Let industry come." He considers that if MPI directors took some of their time-up to 20 $\%$-in consulting or in helping entrepreneurs, this would not only be acceptable but also desirable because of the insights they might receive through knowledge of the potential applications.

A symbol of this desire for cooperation was the establishment of several joint research groups in molecular medicine at the MPI for Biochemistry in Martinsreid in late June this year. The pharmaceutical and diagnostics company, Boehringer Mannheim (Mannheim) and the southern German state of Bavaria will jointly fund for five years three wholly new, but small, research groups at the Max-Planck-Institute for Biochemistry. MPG itself will solely fund two more laboratories in Martinsreid. Patentable results are covered under a formal agreement that allows the MPI researchers to publish, while granting a grace period for Boehringer to make its filings.

What is new about the MPI-Boehringer arrangement is the nature of the collaboration, not that simply that academia and industry are working together. The biochemistry and molecular biology MPIs all have long-standing collaborations with companies like Hoechst (Frankfurt), Bayer (Leverkusen), Schering (Berlin), or BASF (Ludvigshaven), says Markl. But until now, all have been project-orientated or problem-solving activities. Under the recent agreement, fundamental research is being supported. The payoff for Boehringer [and for its new owner, Hoffmann-La Roche (Basel, Switzerland) if the man biotechnology that is hugely disproportionate to the value of the prize on offer-just 10 million marks a year for five years for each of three winning regions. Compare that with MPG's annual biology budget of over DM 750 (US $\$ 838$ ) million.

Markl believes that although there is a strong public relations element to BioRegio. German Federal research minister, Jürgen Ruttgers was very shrewd in hatching the scheme. But he believes that the recent changes in German attitudes to biotechnology would have happened anyway. "The politicians-both the present government and the opposition Social Democrats-became aware that we lost 10 years by discussing only the problems of biotechnology. They saw that Germany imported therapeutics derived from recombinant DNA technology worth about DM 2 (US\$2.2) billion a year, and they realized that [such drugs] could have been produced in Germany, too, if we hadn't been too slow and too problem ridden. People starting saying 'We have heard a lot about the risks. Other countries seem to be generating opportunities and we still only have the risks."

Markl feels that such organizations as the German chemical engineering society, DECHEMA, and its large member companies had exhibited a certain inertia in their defense of genetic engineering during the 1980 s and 1990s. "They were dominated by hard-liners" whose message was in essence that traditional ways have served well, so why change? The huge German trade surplusesaround DM 100-120 (US\$112-134) billion-reinforced that message to the general public. "In Germany, industry was just too successful at that time," he says. "That is no longer the case. . Now, everyone talks about what do we have to do to catch up." II/ 